\title{
The Return to Ethiopia of the Twelve Tribes of Israel ${ }^{*}$
}

\author{
Giulia Bonacci \\ Institute of Research for Development, \\ Université Nice Sophia Antipolis, Nice, France \\ giulia.bonacci@ird.fr
}

\begin{abstract}
Twenty-eight years ago, F.J. van Dijk published in the New West Indian Guide what remained for a long time the only scholarly paper on the Twelve Tribes of Israel. Undoubtedly the largest Rastafari organization both in terms of membership and international expansion, the Twelve Tribes of Israel remains little known in public and academic circles. This article fills two major but closely related gaps in Van Dijk's seminal article. The first is information on the formation and history of the Twelve Tribes, and the second is how the organization mobilized the return of members to Africa, a cornerstone of Rastafari belief. This article argues that the issue of return to the continent determined the very genesis of the organization and subsequently the development of its eighteen international branches. In its turn, this focus on return to Africa offers another perspective on the internal dynamics of the Rastafari movement, namely the structuring role of Rastafari organizations, a role which challenges the common image of Rastafari as an "acephalous" movement. Exploring the tangible relationship of Rastafari with Ethiopia, through the return to Ethiopia of members of the Twelve Tribes of Israel, offers new insight into the history of the Rastafari movement.
\end{abstract}

\section{Keywords}

Twelve Tribes of Israel - Rastafari organizations - Back-to-Africa - Ethiopia - Shashemene

* An earlier version of this article was published in French (see Bonacci 2014). I would like to warmly thank J. Homiak for his attentive reading and constructive comments, as well as R.C. Price and the anonymous referees of NWIG.

(C) GIULIA BONACCI, 2016 | DOI: $10.1163 / 22134360-09001052$

This is an open access article distributed under the terms of the Creative Commons

Attribution-Noncommercial 3.o Unported (CC-BY-NC 3.0) License. 
They took us by boat and we're coming back by plane.

BRO. TRIKA, Shashemene

The Twelve Tribes of Israel is a Rastafari organization prominent both in terms of the number of its members and its presence on the international stage, although these features of the organization are little known in public and scholarly circles. The organization has never used traditional print or electronic media to spread information on its structure and activities. Likewise, its members have traditionally been reluctant to engage with researchers and journalists, and have almost always declined to talk about themselves and their organization. The Twelve Tribes are mentioned in passing in the historiography of Rastafari of the 1970s and 1980s. A handful of citations are noted in Horace Campbell's book (1994:132, 143, 188-89), and a short chapter is devoted to the organization in Leonard Barrett's work (1997:225-34). Because Rastafari members refused to speak to him, Barrett's insights are supported in large part by remarks from persons outside the organization. In 1988, Frank Jan van Dijk published an article in New West Indian Guide that was the first and remains the main scholarly paper to deal in depth with the Twelve Tribes of Israel. Van Dijk's fieldwork lasting five months was undertaken in Kingston in 1986-87. ${ }^{1}$ His research subsequently developed into a book (Van Dijk 1993) and other informative articles (Van Dijk 1995 and 1998). Articles by other scholars have explored the London or Kingston settings of the Twelve Tribes of Israel, primarily with an interest in the theology of the organization and giving only superficial attention to its social structure (Bracke \& Jansen 1995; Bedasse 2010). In a recent article, Bedasse correctly pointed out that the Twelve Tribes is "a unique expression of Rastafari," a "centralized group" that includes middle-class membership and that privileged Rastafari as a "religious experience." While Bedasse did not deal with these points in detail, as her main focus was the return of one Rastafari to Tanzania, she noted that the Twelve Tribes' approach to repatriation was "unique," based as it was on collective mobilization (Bedasse

1 He was then pursuing a Master's degree in cultural anthropology at the Utrecht University in the Netherlands. 
2013:301-2). Despite these other articles, Van Dijk's early article in this journal remains the main reference for what was then identified as a "new' house of Rastafari" (Van Dijk 1988:2). In his article he presented details of the doctrine of the Twelve Tribes of Israel, which he understood as relatively Christian. He also discussed the organization's internal functioning as well as their social composition, which included members of the middle class. All of these elements served to sharply distinguish the organization from other segments of the Rastafari movement (the Ethiopian World Federation, Ethiopia Africa Black International Congress, Theocratic Nyahbinghi Order, and so on). Van Dijk noted that the Twelve Tribes formed the broadest and best-organized group of Rastafari in Jamaica, while stating that information about the total membership was unavailable (Van Dijk 1988:9). ${ }^{2}$ In the final part of his article, entitled "Got to Leave the West, the West Must Perish," Van Dijk underlined the action-driven engagement of the Twelve Tribes of Israel toward return to Africa, and to Ethiopia in particular. ${ }^{3} \mathrm{He}$ wrote:

It is, however, not entirely clear whether the first members of the Twelve Tribes arrived [in Ethiopia] before or after Selassie's downfall, nor is it known exactly how many people are involved in the repatriation.

VAN DIJK 1988:21

This vagueness or uncertainty surrounding the return of members is inconsistent with the centrality of the commitment that motivated Twelve Tribes membership. Just before the Ethiopian revolution (1974), the first members of the Twelve Tribes were sent to Ethiopia, and the organization redefined itself in relation to the wider landscape of Back-to-Africa initiatives and other Rastafari affiliations. The Twelve Tribes' policy of silence concerning actual returns

2 It is difficult to gather precise numbers for the Rastafari movement in general and for the Twelve Tribes of Israel in particular. In 1980, about 2,00o Twelve Tribes members were counted in London (interview with G. Cohen, Addis Ababa, October 4, 2003), several thousands in Manchester, Jamaica, the United States, and Trinidad, with a total membership that might have exceeded tens of thousands. Van Dijk (1988:9) mentioned that member estimates, in Jamaica in the late 1980s, were between 500 and 2,00o, while his own guesstimate was 800 . Ten years later, Hepner (1988a:204) counted several tens of thousands of Rastafari in Jamaica, the United States, and the United Kingdom.

3 While "repatriation" is the term most often used by Rastafari themselves, in scholarly literature repatriation is mostly used to describe the administration developed by states to repatriate their nationals from abroad back to the homeland territory. In this article I use repatriation and return interchangeably, with a leaning toward return. Thus the nonofficial, non state-sponsored mobility to Africa is emphasized. 
is not unlike the pervasive silence of the historiography of Rastafari, albeit for different reasons. While the Twelve Tribes likely kept a low profile to screen their activities from external scrutiny, the blind spot in the historiography of Rastafari on matters of repatriation would seem to serve the intellectual and political interests of scholars who have consistently downplayed the capacity of Rastafari to organize themselves and to translate the idea of return into social practices. The relatively small number of returnees is often used to hide the significance of the practices of return. In fact, the "return to Africa" is a structuring element of the movement that has been surprisingly overlooked, particularly as a material, physical reality. ${ }^{4}$ The link between the formation of the Twelve Tribes of Israel and the return of members to Ethiopia is an intimate one and forms the focus of this article.

In the 195 os and 196os, the Rastafari movement was in full swing in Jamaica, expressing a social critique of colonial and postcolonial Jamaica and pride in African roots and black identity. The latter, it should be noted, was historically negated by dominant colonial values and repressed through violent encounters with the Jamaican state (Van Dijk 1995). The divinity of Ethiopian Emperor Haile Selassie I proclaimed by Rastafari was an additional means for overturning a prevalent symbolic order that associated blackness with servitude, replacing it with the concept of the black body as the site of divinity. A holistic cultural system was developed by the early generations of Rastafari, including forms of ritual and worship, a natural diet, a distinctive language, and symbolic and musical productions, all tending to establish individual and social identities, which were considered highly subversive by the prevailing public opinion. The desire to return to Africa was previously diffuse in Jamaican society, and was interpreted by Rastafari as central to individual and collective redemption, thus becoming a cornerstone of their theology and world vision. Rastafari were not the first diasporic Africans in Jamaica to demand the right to return to Africa (Bonacci 2013a): they were heirs to intellectual and popular genealogies that made return to Africa a necessary step in re-establishing the sovereignty of black people dislocated by Atlantic slavery. ${ }^{5}$ In Jamaica, return was made tangible in 1955 with the news that land had been granted by Emperor Haile

4 Anthropologist Barry Chevannes (1998:31) stated that no return was made after the 196os; and The Rastafari Reader, a collection of reference texts, does not have a chapter on return to Africa (Murrell, Spencer \& McFarlane 1998).

5 The best-known figure of the Back-to-Africa movement was the charismatic and controversial Marcus Garvey (1887-1940). A Jamaican printer, founder of the Universal Negro Improvement Association (UNIA) that had millions of members at its apex in the 1920s, Marcus Garvey is a prophetic and nationalist reference for Rastafari. 
Selassie I in Shashemene, southern Ethiopia. The growing interest in the possibility of repatriation was fueled by the Back-to-Africa mission sponsored by the Jamaican government in 1961, which included three Rastafari representatives, and visited five African countries to study the possibilities of settlement. While the promising results of the mission were forgotten by 1962 , when Jamaica gained independence, three Rastafari organized another nonofficial Back-to-Africa mission in 1963, but to no avail (Bonacci 2013a). The turning point came with the state visit of the Ethiopian emperor to Jamaica in 1966. The visit inflated the enthusiasm of Rastafari, even though they were at the same time violently repressed by the postcolonial Jamaican government.

It is in this context that the Twelve Tribes of Israel was founded and developed into an organization that would permanently transform the Rastafari movement through the centrality of repatriation in its doctrine and its social practices. A close reading of the foundation of the Twelve Tribes of Israel with this focus shows how the issue of return determined the very genesis of the organization and the development of its international branches. The data for this article was primarily gathered in Ethiopia, the "promised land" of Rastafari. However, to document a history simultaneously territorialized in Ethiopia and situated in multiple sites, further fieldwork was conducted in Jamaica and in the United States. ${ }^{6}$ The importance of such multisited research must be stressed. It entails an in-depth approach and provides perspectives on different sites, in Ethiopia and various sites in the Diaspora, an approach advocated by anthropologist Carole Yawney (Homiak 2013:88-89). These various sites are not so much juxtaposed as intimately connected in giving shape to the history of return. This history of return offers another understanding of the internal dynamics of the Rastafari movement, in particular regarding the structuring and mobilizing role of Rastafari organizations, a role that challenges the common image of an "acephalous" movement (Chevannes 1998:31). Untangling the tangible relationship of Rastafari with Ethiopia, through the return to Ethiopia of the Twelve Tribes of Israel, eventually provides another window into the history of the Rastafari movement.

6 The bulk of the data from Ethiopia was gathered between 2001 and 2003, fieldwork in Jamaica took place in 2002 and 2005, and interviews in the United States were carried out in 2005 and 2006. Updates were conducted between 2010 and 2014. 


\section{Entering the Ethiopian World Federation to Return to Ethiopia}

The origins of the Twelve Tribes of Israel must be traced to Vernon Carrington (1935-2005), also known as Gad, Gadman, or Prophet Gad, who in 1968 started recruiting members into his group. Born in Kingston from parents of the lower middle class, Carrington worked in the music industry for the Coxsone Sound System, and in a shoe-making factory. ${ }^{7}$ By $195^{8}$ - the year of a famous all-island grounation held in the heart of Kingston at which those assembled expected to embark for Africa-Gad had already established himself alongside other Rastafari leaders (Price 2009:73). In 1960, like many other Jamaicans, he traveled to the United Kingdom but he remained there only a few months. In one of his rare public interviews, he tells of his "conversion" upon returning from the United Kingdom:

I was being converted in 1961 and I read the Bible from Genesis to Revelation twice. But I was being sent, I was called and sent, resurrected and sent to do this work, and when I read the Bible I strongly see that there is a gap that is there to be filled, and I believe that I am one of them that [was] sent to do it. Do the work.

CARRINGTON 1997

Gad read the Bible twice at the pace of a chapter a day, an exercise that took about seven years. Following this, he had a clear vision of his mission: to gather the scattered tribes of Israel, and bring them home to Ethiopia. To accomplish this two strategies were implemented. First, Gad developed a particular doctrine based on the biblical accounts naming the twelve tribes of Israel coming from the twelve sons of Jacob (for example, Genesis 49). In this he was inspired by Charles Fillmore (1854-1948, Unity School of Christianity) and the American metaphysical movement at the basis of neoliberal Christian fundamentalism. ${ }^{8}$ Fillmore identified twelve seats of power within the human body, corresponding to twelve faculties (faith, strength, judgment, and so on), and to the Twelve Disciples of Christ (Fillmore 1995). Gad's stroke of genius

7 This information comes from a booklet published by the Twelve Tribes of Israel for the funeral of Vernon Carrington which was held in March 2005 in Kingston. The thirteen-page booklet was entitled Blessed Be He that Enlargeth Gad.

8 The theology of Charles Fillmore was founded on the unity and the universality of God, the regeneration of man by Christ, the power of thought and the spiritual interpretation of the Scriptures. Fillmore is the author of the Metaphysical Bible Dictionary (Fillmore 1931), one of the readings recommended by Gad to the members of the Twelve Tribes of Israel. 
consisted in developing a calendar from these correspondences which allowed the members to identify themselves with one of the tribes of Israel based on their month of birth, thus creating a strong and coherent collective body. ${ }^{9}$ Second, Gad registered his group as a local branch of the Ethiopian World Federation (EWF) in Kingston: Local 15. The EWF, founded in 1937 in New York by an Ethiopian Melaku E. Beyen by order of Emperor Haile Selassie I, originated in the popular and Pan African mobilization precipitated by the war between Italy and Ethiopia (1935-41). The objective of the EWF was to centralize the moral and financial support given by black communities in the Americas to the Ethiopian cause. In 1950, Emperor Haile Selassie I granted land in Shashemene, a southern Ethiopian market town, to the members of the EWF as a token of appreciation for their support during the war. The first people to settle there were James and Helen Piper, Garveyites, Black Jews, and EWF members who were originally from Montserrat. In the early 196os, a few African Americans, Muslims, Baptists, and one Rastafari joined them. The first Jamaican Rastafari arrived in 1965, and was followed by groups of Rastafari starting from 1968. The first gift of land by an African head of state to the "black people of the world," Shashemene, was thus put at the center of Back-to-Africa initiatives, particularly in Jamaica. There the EWF appeared to be the legitimate organization through which settlement in Ethiopia could be realized. Local 15 of the EWF, headed by Gad, became well known in Kingston during the early 1970 and was an organization with whom Joseph Owens, who was then doing his fieldwork with the Rastafari in Kingston, had contact. Owens noted their approach to Ethiopia:

The group which is currently most insistent upon pursuing repatriation and is most actively taking steps towards it is Local 15 of the Ethiopian World Federation. Members of that local have almost completely eschewed the notion of waiting passively for their deliverance [and ... are] currently trying to raise money to send small groups to Ethiopia ... Of key importance to them is membership in the Federation, and much of their exhortation is aimed at proselytizing ... Local 15 leaders are convinced

9 For example, a man or a woman born in April was of the tribe of Ruben, her/his color was silver, her/his faculty was faith, the part of the body she/he represented were the eyes, and the corresponding disciple of Christ was Andrew. This system of identification has since then diffused throughout the Rastafari movement, and it is common for non members of the Twelve Tribes of Israel to identify with a tribe. For all the correspondences, see Van Dijk (1988:4-6) and Bonacci (2015:205-8). 
that once people realize the potential of the organization, they will join in vast numbers, save their money, and soon return home to Ethiopia.

Local 15 was thus, in terms of mobilization for the return to Ethiopia, one of the most active places in the Rastafari landscape. It is interesting to note that their proselytizing was closely related to the prospect of return and also to membership in EWF as the organization that would make return possible. However, the charter opening Local 15 of the EWF had not been authorized by the New York headquarters of the Pan African organization, but by Reverend Winston G. Evans, an African American who had presided over an EWF local in Chicago since 1947. Evans had declared his relative independence vis-à-vis the New York headquarters of the EWF, illustrating the fault lines and fragility of the organization. ${ }^{10}$ For Rastafari in Jamaica, however, it was significant that Evans had met Emperor Haile Selassie I, in the United States in 1954 and when visiting Ethiopia in 1968. During his visit to Ethiopia, Evans had requested and received land in the Bale Mountains, a beautiful and remote region east of Shashemene. A photograph of the Emperor and Reverend Evans shaking hands later appeared in African Opinion, ${ }^{11}$ which encouraged Gad and his group to be in contact with him (see Figure 1).

Thus in 1970, the members of Local 15 in Kingston received Evans with enthusiasm. They had confidence in his promise to send scores of members to Ethiopia and began to send him their weekly dues. In the absence of any concrete progress, however, Gad decided to visit the EWF head office in Chicago. Accompanied by Ivan Coore, another Rastafari, he left for Chicago only to return home extremely disappointed. Not only were the members of Evans's local old, but Evans steered clear of the two Jamaicans in order to avoid a discussion of financial issues which would quite likely have resulted in a confrontation. Disappointed, the Jamaicans returned to Kingston where they qualified the EWF as a "joke" and a "fraud" and recognized that the charter establishing their local was probably illegitimate. ${ }^{2}$ The investigation continued. Gad and other officers of his local visited Ethiopia, where they remained for a month. They went to Bale where they noted that the donated land was neglected. They

10 Rev. W.E. Evans, EWF Chicago to G. Ascott, Kingston, October 14, 1967, Archives of the Ethiopian Orthodox Church, Maxfield Avenue, Kingston.

11 African Opinion $8(3 \& 4)$ 1967:5.

12 Interview with R. Morrison, Kingston, March 22, 2002. All interviewees in this article have given their permission to be named and quoted. The quotations in Jamaican patois have been only minimally edited in order to facilitate reading. 


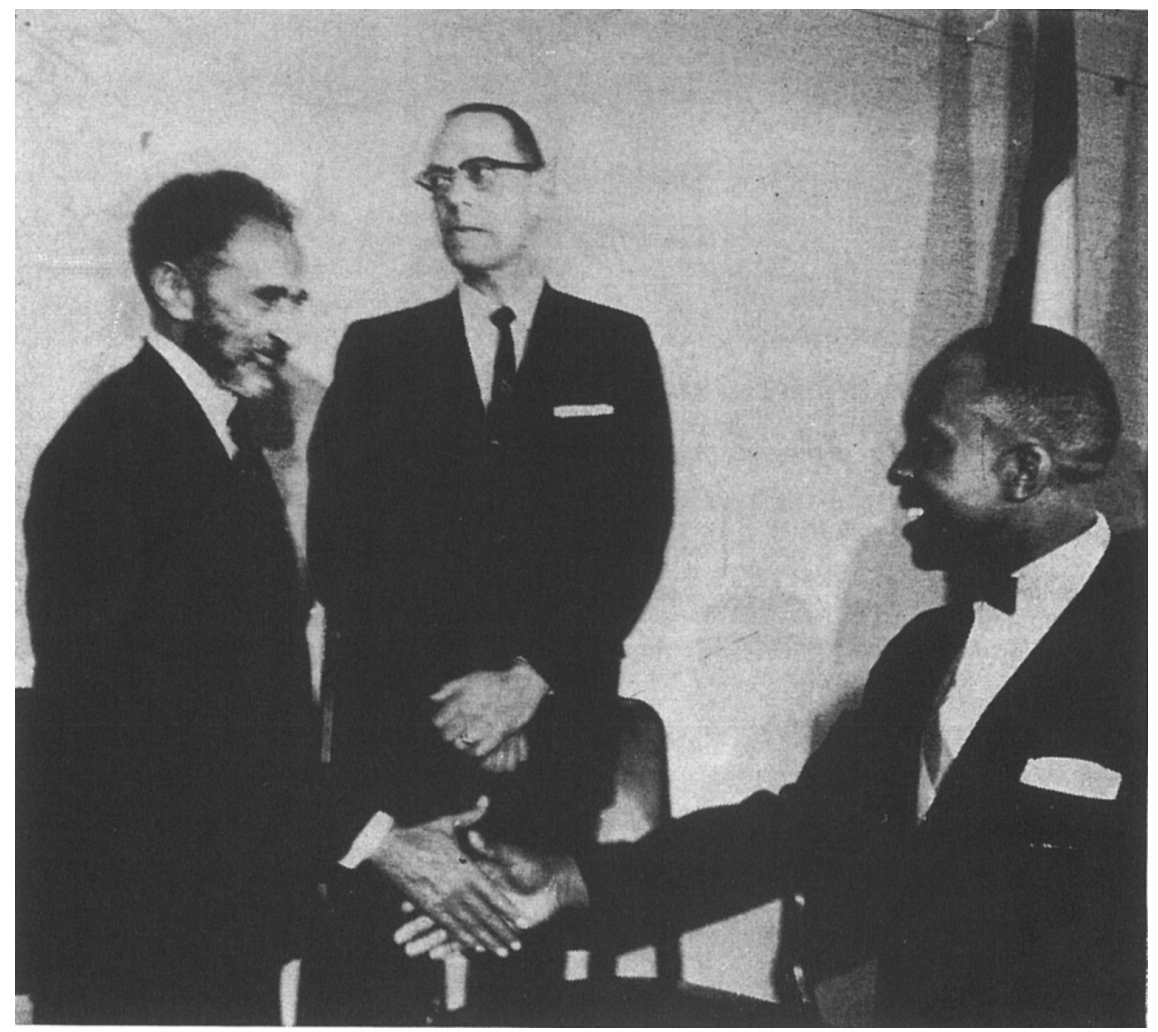

FIGURE 1 Haile Selassie I and Reverend Evans shaking hands in Washington, D.c.

later contacted the returnees residing in Shashemene and the Ethiopian government. ${ }^{13}$ On their return to Jamaica, they presented a detailed report to the members of the local, to whom they also presented a symbolic handful of soil collected in Ethiopia. ${ }^{14}$ Seeing the land was like getting tangible "proof" of its availability, not in Bale, which was too remote, but in Shashemene, where several Jamaicans had already settled. At the time, Local 15 counted 118 highly organized members and was ready to send the first of them to Ethiopia.

Local 15 then turned toward Local 43, headed by Solomon Wolfe, which had a charter delivered in 1958 by the New York headquarters of the EWF and was by then the only Jamaican local with active bonds with Shashemene (Bonacci 2013 b). Gad proposed that members of Local 15 join Local 43 in order to remain

\footnotetext{
13 Interview with R. Morrison, Kingston, March 22, 2002 and E. Smith, Shashemene, May 3, 2003 .

14 Interview with D. Martin, Shashemene, January 28, 2003.
} 
within the legality offered by the EWF. However, he met with strong reluctance from the acting officers of Local 43 while its president, Solomon Wolfe, was in Ethiopia. The Chaplain of Local 43 relates his reaction to Gad's proposition:

When Gad come fe [to] hand over the people and the money to EWF, I man [I] refused ... No organization respecting the leadership can suddenly hand over to another organization without some kind of agreement as to what it is all about, consolidation or merging of two bodies under what condition ... Not a case when you hand over your money and your people and say do this [and] hand over to you. So what happen to you? What happen to your administration? Not so. ${ }^{15}$

This defensive position illustrates the importance the officers of EWF Local 43 accorded to its administration. They had overcome many organizational difficulties: short-circuiting the established channels of the EWF controlled by non-Rastafari, transforming the EWF to prioritize repatriation, obtaining passports and visas, organizing departures by air, establishing the local in Ethiopia and working to keep members of the Jamaican local mobilized. The impossibility of cooperation between these two locals of the EWF was to have a great impact on the Rastafari movement in its push towards the foundation of the Twelve Tribes of Israel.

\section{Becoming the Twelve Tribes of Israel}

Since its formation in 1968, Local 15 had developed a particular form of doctrine and internal organization called the Twelve Tribes of Israel. It had affiliated with the EWF in the conviction that the latter was the legitimate organization through which repatriation to Ethiopia would occur. The knowledge that Reverend Evans had misled them and had made fraudulent use of the EWF label, and the refusal of Local 43 - the only one with active bonds in Shashemeneto merge with Local 15, caused Gad's group to give up their intention of collaborating with the EWF. Local 15 chose to rely on their own organizational, economic, and doctrinal principles, which were the very principles that Local 43 saw as a threat. Due to the dysfunction of the EWF, the Twelve Tribes decided not to recognize its legitimacy and to seek their own means of accomplishing return. As one of the members explained it:

15 Interview with B.J. Moody, Shashemene, April 1, 2003. 
Even with [Ethiopian World] Federation we were functioning Twelve Tribes of Israel. Two organizations, we sit up Twelve Tribes, like a church. Federation was the state part of it. We function both Twelve Tribes of Israel and Federation. It was easy to rest Federation and own the function as Twelve Tribes of Israel, free from attacks and things government could try ... Chapter 15 wasn't legal some say, so Gad say let's function Twelve Tribes. There is the Federation thing but we [are] ready fe deal wid something positive, and it seems like a skeleton, just like a ghost. There is no administrative body as such of the Federation. Federation didn't take the people home ... If Federation say people sent back to Africa, is Gad who did that through dues and buying tickets—none of dem did this ... If Federation was to investigate, Federation would go to prison. Where did the money go? Like Marcus Garvey. Gad warned that Garvey mistake is a landmark. Something else but not Federation. Federation died. ${ }^{16}$

The distinction between the two organizations was formulated in terms of functions: on the one hand, a "statical," official function, represented by the EWF, and, on the other hand, a "churchical," ecclesiastic function, filled by the Twelve Tribes. Whereas the EWF was an ecumenical organization to which Rastafari had difficult access, the Twelve Tribes formulated a unitary doctrine, which all its members accepted and which excluded those who did not share it. This doctrine included the pooling of resources through a weekly contribution by members and a program of events. While under the aegis of the EWF, the funds collected weekly were sent to Reverend Evans and the Chicago Local, but these were obviously squandered. This was the meaning of the reference to Marcus Garvey, who had been accused of fraud in 1923, found guilty and jailed in an Atlanta penitentiary until his deportation from the United States. The financial fraud that undermined Garvey and his organization was interpreted as a precedent to the fraud committed by Evans in the name of the EWF. On rejecting the EWF, Twelve Tribes members were able to control and dispose of the funds they collected themselves. The name "Twelve Tribes of Israel" for Local 15 was chosen in 1973, but it was applied retroactively from the foundation of Local 15 in 1968. For its members, the foundation date of the Twelve Tribes is therefore 1968. The consequences of the separation of the EWF and the Twelve Tribes of Israel are still visible today in the settlement in Shashemene, especially in terms of legitimacy, power, and sociability and, more broadly, in the international diffusion of the Rastafari movement.

16 Interview with A. Nevers, Shashemene, September 28, 2003. 


\section{Eric L. Smith, the First Member to Return to Ethiopia}

Born in 1949, Eric L. Smith grew up in the neighborhood of Trench Town in Kingston. His parents were Christians. Because of their poverty, he dropped out of school around age ten to learn to fend for himself. Near age twelve or thirteen, he was already in contact with Rastafari. From them he heard about the teachings of Marcus Garvey and about the 1961 and 1963 Back-to-Africa missions. At age nineteen, he met Gad and became one of the first members of the organization, which was functioning at the time as EWF Local 15 . He explained his reason for becoming a member of the EWF:

The whole thing is back to Africa, repatriation to Africa that was the cry of the Rastaman, that was my aim and desire, to return back to Africa. So I start Federation as a means to return back to Africa, cause at the time, most Rasta couldn't really afford a ticket to come to Ethiopia, including myself. Now the Federation work co-operatively, a ticket could be purchased for any member that was chosen to come. That's even how I get a chance to reach here. ${ }^{17}$

Eric Smith had met Reverend Winston G. Evans during the latter's visit to Kingston. The young Rastafari became an executive member of the organization, ${ }^{18}$ and was given the name of Asher $1^{\text {st }}$, but he relinquished his seat on the first bench to someone else. When Gad returned from the visit to Ethiopia, he was quickly called: was he ready to leave for Africa? He answered yes, accepted his plane ticket and had very little time to prepare for departure. He left behind a woman and a three-month-old baby who did not survive. He left for Ethiopia on September 28, 1972, where he arrived after a two-day journey and a transit through London. After a few days in Addis Ababa, where he met a Jamaican university student on an Ethiopian government fellowship, he made a day-long journey to reach Shashemene. There, Desmond Christie, an

17 Interview with E. Smith, Shashemene, May 3, 2003.

18 The executive body of each branch of The Twelve Tribes of Israel was made of twelve brothers, each representing one of the tribes (first bench), and their "shadows," twelve other brothers on the second bench; twelve sisters each representing one tribe (first bench), and their shadows, twelve other sisters on the second bench; and Sister Dinah (the "only lady child that Jacob had"), making an executive body of forty-nine persons. Various responsibilities were distributed among the executive members: an overseer, a general manager, a treasurer, heads of the various committees, art, music, sawing, social activities, and so on. 
EWF member from the United Kingdom who had arrived a few years prior, welcomed him. The two hundred hectares of the land grant at the periphery of Shashemene had been divided in July 1970 among twelve people, a few small houses had been built, the land was partly cultivated, and the rest served as grazing land (Bonacci 2015:288-93). Smith was the first of a number of people sent by the Twelve Tribes of Israel. Three months later Millward Brown (Dan) followed him, then Brother Green (Simeon) who "couldn't cope with the conditions, so he went back to Jamaica." 19 The physical and cultural isolation of this twenty-person settlement cannot be underestimated. Limited financial resources, difficult access to drinkable water, and an absence of medical infrastructure were major challenges. In 1973, Brother Leard (Benjamin) arrived but rapidly became sick and passed away in a hospital in Addis Ababa. He had time to share an important piece of news with the first members settled in Ethiopia: the name and the structure of the EWF had to be dropped, and the organization known only as The Twelve Tribes of Israel. As Smith explained, this did not radically transform the relations between the various Rastafari settlers:

Well to be truthful, to the old Federation members, the Twelve Tribes was kind of strange, they were indoctrinated in the Federation thing, and the Twelve Tribes thing is dealing with Jesus Christ as the returned Messiah, so that created differences between we and those old Federation. But it wasn't too obvious then to really create a division. Their belief is their belief and they do not accept Jesus Christ and we say Rastafari is Jesus Christ revealed in the personality of His Imperial Majesty [Haile Selassie I]. We are orthodox, this is orthodox teaching, but we understood the difference and we don't make that become a problem, so we just go through still with them as Rastaman. ${ }^{20}$

Smith expressed the distinction between the two organizations in religious terms: beyond the existence of different administrations, there was a difference regarding the nature of Haile Selassie I. At the time, for the majority of Rastafari, Jesus Christ was seen as prerogative of the Christian churches of missionary origin whose proselytizing concerned a "white Christ." The Rastafari of the Twelve Tribes appropriated the Christian discourse and constructed their unitary doctrine around the recognition of the second coming of Christ, manifested in the

19 Interview with E. Smith, Shashemene, May 3, 2003.

20 Interview with E. Smith, Shashemene, May 3, 2003. 
"personality" of the emperor, while distinguishing between the two figures. It should be noted that this patently Christian leaning is one of the elements that ensured the success of the Twelve Tribes in Jamaica, a largely Christian nation. Such an interpretation was acceptable especially in the light of the fact that many of the speeches of Haile Selassie I referred to the Bible, Christ, and the Christian Orthodox Church of Ethiopia. The doctrine regarding the nature of Haile Selassie I had an important impact in Jamaica, where the Twelve Tribes represented a unique alternative in a landscape dense with Rastafari associations that emphatically rejected their Christological perspective.

In Ethiopia, however, the tiny size of the isolated Rastafari community meant that theological differences between the settlers were downplayed. But in 1974, the small community was hit by the repercussions of the Ethiopian revolution. A military committee called the Derg took power, the emperor was deposed, and the social and political landscape of Ethiopia was deeply shaken. The Rastafari were associated with the emperor because of their faith and their privileged access to land. By March 1975, when land was nationalized in Ethiopia, they had lost their land, their houses, and their harvest. Only a few board houses were kept, but most of the settlers actually left the country in the years following the revolution. They felt threatened, and were subject to food rationing, curfews, the effects of the civil war and many other restrictions that were sweeping the country. An officer of the EWF who went to Ethiopia from London in 1986 summarized it succinctly:

Those that remained are the real pioneers cause if they wouldn't remain, the land grant would have been ... It would have been the end of the Rasta movement so to speak, it would have been written off as another cult, like the hippies. But the fact that we had land granted, a gift, saying thank you for the help of our parents, through the Federation again, had given Ethiopia, it couldn't be written off as a myth. ${ }^{21}$

Those who stayed, joined by a few young members of the Twelve Tribes of Israel, played an important role. In the midst of social and political change, their presence assured a future for the Rastafari movement, and the realization of the myth prevailed. They were just a handful of people, and the return was altered and slowed down because of the political situation in Ethiopia.

21 Interview with T. King, Addis Ababa, August 10, 2003. 


\section{A Return Impeded by the Ethiopian Revolution}

Members were sent to Ethiopia based on the order that they had joined the Twelve Tribes of Israel. The call to leave everything behind in order to join the collective project of gathering the Twelve Tribes in Shashemene was a masculinist project, reminiscent of Christ who asked his disciples to give up their activities and families to follow him, to let "the dead bury their dead" (Matthew 8:22). Some male members who were recently married were told that their wives would follow, while others had to leave them behind. Some did not have the heart to give up their wives, but others did so. Anthony Nevers (Issachar), who left behind a pregnant woman and a child, recalls the difficulty and the stake of this act:

We know we some stone heart [laughs]. Some people say we was stone heart people, that we never give a damn, but it wasn't like that, a true you don't know, we missed beloved ones, yeah, but a sacrifice we know we have to make, it was so fortunate- or say unfortunate? - that it had to be me as Issachar that would have to step forward for holding that seat. I was just twenty years old. One of the youngest yout' who a came through ina dem time. Even years after years you realize the bold step of that time. ${ }^{22}$

The intermingling of sorrow and determination is palpable in the words of Brother Nevers. Allegiance to the organization, pride in taking part in a prophetic project, realizing the goal, and the responsibility of representing one of the tribes in Shashemene were all counterpoised with angst over their personal and familial situation. Realizing the return was clearly a sacrifice and as such it reflected both the prophetic and the patriarchal leanings of the Rastafari movement. Although the Twelve Tribes included participation of women in its structure, a male orientation characterized the internal and public functions of the organization and pioneering nature of the settlement in Shashemene. The kinds of personal and family tensions associated with departure from Jamaica influenced family practices in Shashemene, which ultimately gave more "value" to the incorporation of Jamaican women as compared to their Ethiopian counterparts who had a different language and culture (Bonacci 2015:327-37). Norval Marshall (Dan) was an exception among the Twelve Tribes members who traveled to Ethiopia, as he himself financed the ticket for his son:

22 Interview with A. Nevers, Shashemene, September 28, 2003. 
Being a member of the organization, we were called up in a meeting and what the Prophet [Gad] ask us is if we are ready to go to Ethiopia. And we say yes. Are you ready to leave your wife and kids? Cause I had a woman and a baby boy. Are you ready to leave your mum and everything you have? Me say yes ... It wasn't her [his wife's] time, not her turn to come. People had their turn in according to when you joined the organization. So they were sending me and after that I was promised that my wife would come and I wanted my son to travel with me, I wasn't leaving him. So I brought him. We came here. ${ }^{23}$

When his turn came, the organization paid for his plane ticket, leaving him with two things to do. First, he had to apply for a new passport as his had just expired. An executive member with relations in the government obtained him a new one- - one of the advantages of membership in an organization with contacts in the middle class and in the political and social elite. Second, he had to organize a dance, as was the practice of most prospective returnees, to raise funds for an easier settlement in Ethiopia:

This was my first and only dance until today in my life, I never kept another dance. There was a send-off dance, and I came with a lot of money, maybe I came with I can't remember exactly now, but I sure I came with like 5,00o Jamaican dollars at that time, or more, which could get me a nice č'eqa [cob] house even, like that or maybe bigger. ${ }^{24}$

The send-off parties for members also served an important public function. Every dance served to publically announce that the Twelve Tribes were actually sending people to Ethiopia and facilitating repatriation. The Twelve Tribes were reputedly "the house of reggae." More than any other Rastafari group, they contributed to the explosion of reggae, which they called "the music of the king" (Hepner 1998b: 144). Twelve Tribes reggae parties still bring back vivid memories in Kingston, and accounted to a great extent for their success.

The year 1976 drew to a beautiful end for the Twelve Tribes: in December, thirteen members of the organization traveled to Ethiopia together. The Daily Gleaner published a photograph of those who accompanied the travelers to the airport, and mentioned "hundreds of happy and peaceful 'brethren' and 'sistren' who wore banners (knitted tams) of red, gold and green which are the colors

23 Interview with N. Marshall, Shashemene, September 27, 2003.

24 Interview with N. Marshall, Shashemene, September 27, 2003. 
of the Ethiopian flag." ${ }^{25}$ Six executive members and Sister Dinah accompanied the would-be settlers in order to make a report to the headquarters. Six others had the intention of settling in Ethiopia. However, only three of them remained: Patrick Campbell (Zebulon), Anthony Nevers (Issachar), and Vincent Wisdom (Naphtali). One did not want to leave his wife in Jamaica, and the others were probably discouraged by the military atmosphere that prevailed in Addis Ababa and by the tense social situation in Shashemene. As the news of the new military regime in Ethiopia was received in Jamaica, the letters written by the transatlantic migrants circulated and were read in Kingston, becoming the focus of a lively commentary. These missives reported the increasingly difficult financial and social situation in Shashemene, and advised slowing the sending of members, since their safety could not be guaranteed and the land concession had been severely curtailed following land nationalization in March 1975. As a consequence, some members refused to leave when it was their turn, which created tensions within the organization. Winston Simons, born in 1945, was of the tribe of Benjamin. Three persons from his tribe refused to leave prior to his turn. He was only the fourth in line, but in 1981 he was the one to arrive in Ethiopia. In Shashemene he met his brother who had arrived in 1977, and his wife quickly followed him. The young members of the Twelve Tribes of Israel arriving in Shashemene after the mid-1970s had to survive in a new and politically unstable environment. They learned basic Amharic, but as subsistence agriculture was not sufficient to feed them they relied on characteristic Jamaican creativity. They made coffee tables, combs, beds, cupboards, and pantries until restrictions on raw materials limited their production. To the extent that conditions in Ethiopia allowed communication with the outside world, the settler community mobilized its networks with the international branches of the Twelve Tribes in an appeal for resources. The large branches in Western metropolises, in particular, played an important role in the survival of the small community by sending remittances-in itself an interesting inversion of the pattern historically found in Caribbean migrant communities.

\section{The International Development of the Twelve Tribes of Israel}

One of the indirect consequences of the Ethiopian revolution was the international development of the Twelve Tribes of Israel. As returns to Ethiopia slowed,

25 Daily Gleaner, December 10, 1976. 
the organization itself continued to develop internationally with the establishment of eighteen branches: in 1976 in New York (United States) and Manchester (United Kingdom); in 1977 in Port of Spain (Trinidad); in 1979 in London(United Kingdom); in 1981 in St. George's (Grenada); in 1985 in Bridgetown (Barbados), Toronto (Canada), Los Angeles (United States), and Scarborough (Tobago); in 1986 in Georgetown (Guyana), Nairobi (Kenya), Accra (Ghana); and later in the 1990s-20oos in Weiden (Germany), Brisbane (Australia), Paramaribo (Suriname), Auckland (New Zealand), Stockholm (Sweden), and George Town (Cayman Islands). ${ }^{26}$ The opening of these branches followed a similar protocol. A local person on the spot, with the endorsement of Prophet Gad, was given the authorization to open the branch: an American in New York, a Trinidadian in Trinidad, a Kenyan in Kenya, and so on. The embryonic branch took the name Brotherhood of Rastafari while waiting for the forty-nine executive members (twenty-four men and women from each tribe and Sister Dinah) to come together as "full benches." This process of homologation protected the organization from the difficulties arising from incomplete or fragile branches. A member of the London branch explained the activities of these new branches:

Gadman told us the purpose is to publish the word and gather the people ... Very simple you'll do things, when you finish one stage, you'll get more instructions. So we had executives, members, meetings, executives' dances, members' dances, color parties, all stage of dances and celebrations, and we had program with international functions, khaki, leather, and suit. ${ }^{27}$

The reggae dances of the Twelve Tribes of Israel—with regimented forms of dress and color themes - served to mark the identity of the individual "tribes" of Israel and to illustrate the various steps in the development of each international branch. The inclusion of members from the middle class, and of white members, were two of the important innovations of the Twelve Tribes in Jamaica (Van Dijk 1988:4, 11, 13-14). While this often caused them to be considered an inauthentic segment of the Rastafari movement, it did contribute to the evolution of its sociological composition. Given the inclusive

26 There is no direct and easy way to ascertain the locations and dates of establishment of the international branches. An additional branch might be located in St. Vincent in the early 1980s. I would like to thank Larry Curtis and Timothy Green for their help in gathering and verifying this data. 
racial policy of the Twelve Tribes, its members sometimes came from different cultures, but most were middle-class individuals or wage earners, at least in the large cities (Hepner 1998b: 142-43). In New York, the organization, headed by a white American, was situated in a neighborhood with a Caribbean majority and most members were Jamaicans. Jamaicans were far less numerous in Los Angeles, whose branch included migrants from various other locations. The multiethnic character of Los Angeles was reflected in the Twelve Tribes membership there, which included Jamaicans and other Caribbean people as well as African-Americans, Native Americans, Chicanos, and Euro-Americans. White people, who were allowed to become members, flowed into the organization, especially in England, attracted by the culture, the music, and the rebellious symbolism of Rastafari. They contributed to the sharp distinction between the Twelve Tribes and other Rastafari organizations.

The proselytizing of each branch of the Twelve Tribes, a very centralized and organized organization, gave precedence to the theme of return to Africa, and to Shashemene in particular. "Ethiopia is the key of the Twelve Tribes," insisted Larry Curtis (Benjamin), the founder of the New York branch. It was the objective of the collective and financial efforts, despite the fact that for many years arrivals in Ethiopia were few and far between. After Brother Karl Hamilton (Zebulon), who was sent to Ethiopia by the New York branch in 1979, the next two arrivals were in 1981: Handell Paris (Ruben) from New York and Brother David (Issachar) from England. Unable to obtain residency status in Ethiopia, they were deported by the Derg to Tanzania, where Handell Paris died. While new settlements in Ethiopia were jeopardized, the international branches sent their executives to visit and report on the Shashemene settlement as soon as they were able. This mobility was rapid in the case of New York, but elsewhere several years' preparation were required. In the 1980s, six branches were able to send their executive members to visit Shashemene. This was a proof of their proper functioning and a milestone in their development. In Shashemene, private photographs of various residents testify to the importance of these visits. From New Zealand, Trinidad, England, the United States, Germany, and Canada, the whole world went to Shashemene with faces of all colors, and from all of the twelve tribes. Among some residents of Shashemene, childhood photographs or photographs of relatives are rare, in contrast to photographs representing the multiracial mingling of the Twelve Tribes, experienced as an extended international family.

The moral and financial support provided by these visitors was important for the branches that sent them, as it validated their proselytizing in favor of the Shashemene settlement. But it was even more important for the residents 
in Ethiopia. The founder of the New York branch, making a direct reference to the role played by the organization in the lives of the returnees to Shashemene, declared: "We kept them alive." ${ }^{28}$ With the fall of the military government in 1991, the borders of Ethiopia reopened, and in 1992 an international coalition of Rastafari organized a three-week celebration of the centenary of Haile Selassie I. This was a watershed event that signaled the resumption of return for the Rastafari. Members of the international branches sometimes visited Ethiopia "out of their pocket" when their branch was too slow in doing things or in sending executive members to visit. This tendency developed especially in the 1990s, a period during which many members financed their own departure and settlement, bearing witness to the fact that the members of the Twelve Tribes had greater access to finances than when the organization operated in Jamaica alone. Furthermore, when the Jamaican members migrated to Englishspeaking urban centers, where they were usually able to improve their standard of living, they joined the local branches and gave added life to the international network formed by the Twelve Tribes. Albert Allen(Issachar) is a good example in this regard.

A mathematics teacher born in Jamaica in 1956, Allen nurtured the hope of leaving for Shashemene. Facing the slow-down induced by the situation in Ethiopia, he decided to migrate to England in 1987 and stayed there for four years. He took the opportunity to specialize in civil engineering, and then left for the United States in 1991. He settled in New York but traveled extensively. Not wanting to get stuck in the United States, and heeding the encouragement of other resident members of the Twelve Tribes, he finally left for Ethiopia in 1997 via Germany. He financed his own trip because:

One of the things we learned in the earlies, is whosoever who can afford their fare should pay it so that you take off pressure from the organization, so we paid our own fare and went to Germany, cause there's a house in Germany, we stayed for six weeks and come from Germany into Ethiopia. We arrived with 250 dollars with the intention to start a school. ${ }^{29}$

He arrived with more money than his predecessors had twenty-five years earlier. He was also older than the early returnees, with more experience and

28 Interview with L. Curtis, New York, April 16, 2006.

29 Interview with A. Allen, Shashemene, September 9, 2003. 
with recognized skills as a teacher. In their footsteps, however, he left behind a woman and six children. The international branches of the organization served as milestones and way stations for Jamaican members engaged in the process of return. Winston Laurence (Gad), also a Jamaican member since 1975, followed a similar itinerary. He first left for Germany, where he remained for a month, then for Ghana in 1993, where he stayed five years at a time when the local branch was in development. Due to malaria and medical problems, Laurence decided to leave the African coast and went instead to Ethiopia in $1998 .^{30}$ In Shashemene, the eighteen lots of land provided by the government in 1986 (Bonacci 2015:323-25) were not sufficient for the influx of the late 1990 s and early 200os. This had an important consequence, that is, the increasing financial value of the land:

Very quickly the land became highly monetarized [sic] because people coming from the West were coming and wanting to buy land. For the first time you had a reason why people wanted to get control of that land, because it was worth money. ${ }^{31}$

In the very different environment of the early 200os, no longer on rural land but on urban land controlled by the municipality, Rastafari settled by the hundreds, helped by the emergence of middlemen facilitating dialogue between returnees and local authorities, thus facilitating their access to land. About eight hundred Rastafari, members of the Twelve Tribes of Israel and of other Rastafari organizations, as well as non-affiliated Rastafari, live today on the periphery of Shashemene, in what has become known as the Jamaica sefer or Jamaican neighborhood.

\section{New Challenges of the Twelve Tribes of Israel}

Since 2000, and in the wake of the Western Millennium and the Ethiopian Millennium, ${ }^{32}$ many Twelve Tribes members settled in Shashemene, especially those from Trinidad and Tobago, and the United Kingdom. They no longer

$30 \quad$ Interview with W. Laurence, Shashemene, September 24, 2003.

31 Interview with G. Cohen, Addis Ababa, October 4, 2003.

32 Ethiopia uses a Julian calendar that is seven to eight years "behind" the Western (Gregorian) calendar. The year starts on September 12, and is composed of thirteen months, twelve months of thirty days and one month of five or six days. The festivities for the Ethiopian Millennium therefore started on September 11, 2007 (Gregorian calendar). 
relied on their "order" of entry into the organization, and returned on their own means. They developed community houses in Shashemene that served to accommodate newcomers while their settlement was processed, and to alleviate the burden on the historical Headquarters of the Twelve Tribes in Shashemene, which did not have the capacity to host all the returnees. The "disorder" of these arrivals brought many new faces and families to Shashemene, while weakening the traditional channels of authority within the Twelve Tribes. ${ }^{33}$ This became an acute issue in 2005 when the founder of the Twelve Tribes passed away.

The Twelve Tribes of Israel lost its founder, Vernon Carrington, Prophet Gad, on March 22, 2005. A funeral and memorial was celebrated in Kingston and two members residing in Shashemene were invited to participate in the event. A booklet published for this occasion testified to the humble beginnings of the Twelve Tribes in Kingston's ghettos and demonstrated-with texts sent from the international branches - the impressive growth of the organization. However, as in many Churches and congregations, the disappearance of the charismatic and authoritarian leader opened the door to power struggles as individuals made contending claims to succeed the founder. While financial resources are especially found tied to their music label in the United States, Orthodox Music, the prevailing divisions also reflect the symbolic genealogies of power associated with the organization. In Ethiopia, this is visible in the growing rift between various factions of the Twelve Tribes. The former leader of the international branch in Sweden leads a community founded in Bahar Dar, in northern Ethiopia. This group attracts increasing numbers of members, originating in large part from the United States and northern Europe. They have only distant contacts with the Shashemene community. In Addis Ababa some members, established or just arrived, are working to open a formal branch of the organization there, for which they have to gather the executive body of forty-nine people. Both these initiatives seem to be facing resistance and hostility from long-established settlers in Shashemene. In Shashemene, these new initiatives are perceived as deflecting attention away from the original land grant and the Shashemene community's ongoing needs, and jeopardizing the sustainability of this historical settlement.

In November 2012, the Twelve Tribes of Israel hosted an event in Addis Ababa, identified as an important step in their development, which called for

33 This "disorder" is not specific to the 2000s. From the early days of the Shashemene settlement, there was unrest caused by members who refused to go to Ethiopia when their turn came, or who decided to leave the organization once in Ethiopia. Interview with I. Coore, Kingston, August 21, 2010. 
the immediate return of all members to Ethiopia. The event was called the Ethiopian Ball or Shama Ball. The poster announcing the event displayed all the symbols characteristic of the Twelve Tribes dances (see Figure 2). These included the name of the organization inscribed on the Star of David and the Christian cross, representing the double Hebrew-Christian heritage claimed by the Ethiopian Crown, and the thirteen stars representing the twelve sons of Jacob, each in the color of its tribe, and their sister Dinah, represented by the multicolored star. The dress code was strict. Members had to wear the traditional Ethiopian fabric, the shama, for four of the nights, and dress in red for the fifth night, red being the color associated with the month of November and the tribe of Gad. The poster also mentioned the nights restricted to members and their guests, and those open to the wider public, and included a photograph of the Ethiopian royal family, quotations from Emperor Haile Selassie I and from the Bible, and a detailed program involving devotions, music, and a stage show. The line-up of artists included resident members, Ethiopian guests, and international visitors.

To the consternation of many, the struggle taking place within the organization came into the public view during the event, around the person of Zere Yacob Asfa Wossen, Haile Selassie's grandson and heir to the Ethiopian crown. It appears that the future of the Twelve Tribes of Israel could center on the issue of whether or not to support him as successor to the Emperor. Welcomed and taken care of by Twelve Tribes members during the years of exile, in particular in Manchester, England, Zere Yacob has been close to the organization for many years and married a Rastafari sister. For some members he has come to embody the figure of Christ previously represented by Emperor Haile Selassie I. In 1997, Prophet Gad announced the restoration of the monarchy in Ethiopia. ${ }^{34}$ Ignoring the fact that the Ethiopian crown was no longer a reality on the Ethiopian political stage, some saw the Shama Ball, formally presided over by Zere Yacob Asfa Wossen, as an additional step toward this restoration. Heated debates on the nature of the heir apparent divided members, debates over whether he was royal and/or divine, and on what role he would play. Questions were raised as to whether to restore the monarchy in Ethiopia, give new impetus to the organization of the Twelve Tribes, or perpetuate the vision of Rastafari at the dawn of the twenty-first century-in the conviction that a new king in Ethiopia would fulfill the promise of return to his kingdom.

34 Carrington 1997, radio interview conducted by Mrs. Andrea Williams on IRIE FM in Jamaica. 


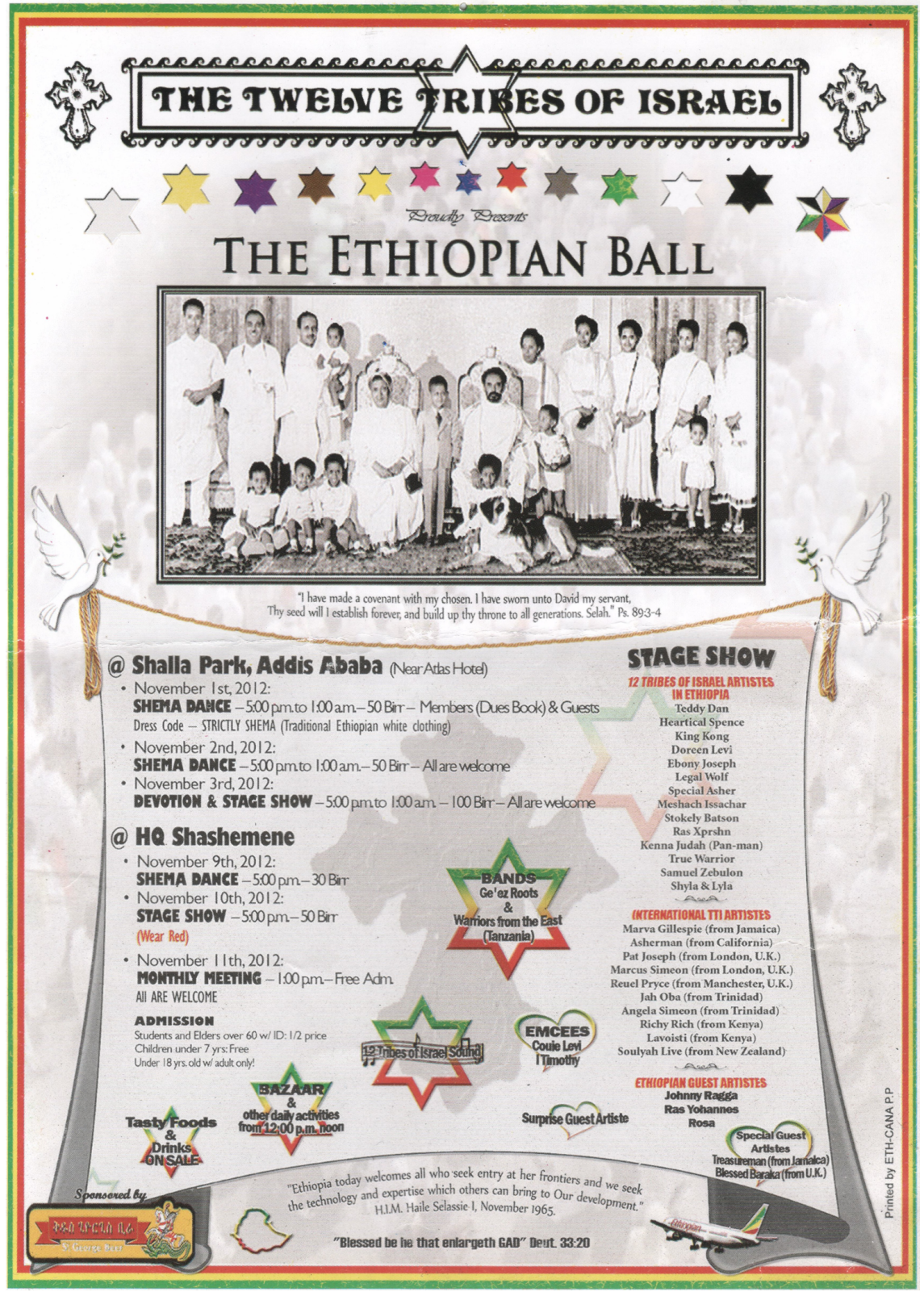

FIgURE 2 Poster of the Shama Ball, November 2012, Addis Ababa, Ethiopia 


\section{Conclusion}

Engagement in the EWF, and a subsequent break with that organization, signaled the birth of another organization within the Rastafari movement: the Twelve Tribes of Israel. This separation was due to the structural fragility of the EWF, and it was facilitated by the particular doctrine of the Twelve Tribes, which gave form to a strong and coherent collective body. The doctrine of that body was influenced by the theology of Charles Fillmore and adapted to the Jamaican context to facilitate the identification of members with the scattered tribes of Israel, an identification that was supported within the cultural sphere by reggae music. A modernized version of the Rastafari movement, the Twelve Tribes fashioned their success by remaining close to one of the main tenets of the movement: return to Ethiopia. Thus the Twelve Tribes both gave structure to the desire to return, and was structured by the practices of return. It was the only Rastafari organization able to fund the departure of some of its members to Ethiopia; physical return being the main objective and driving force of all branches, Jamaican and international. Following a development marked by various stages, each branch had to validate itself by sending its executive members to report on the settlement in Ethiopia, and then by sending its members, by order of enrollment, to settle in Ethiopia. Although well conceived and organized, this blueprint for return proved difficult at times. The reluctance of some members to leave for Ethiopia, especially after the Ethiopian revolution of 1974, and the difficulties of the settlement under the military regime threatened the success of repatriation. And later, the rapidly increasing number of members who did not want to wait their turn also posed problems for the original plan.

During the 2000s, members of the Twelve Tribes from very different backgrounds met in Shashemene. The international expansion of the organization was reflected in the Ethiopian settlement and challenged the Jamaican primacy within the movement. Today, Twelve Tribes members form a majority of the settlers in Shashemene and the organization finds itself at another turning point. The ethnic and economic diversity of its members, the adaptation to the realities of Ethiopian society, and a reconfiguration of the doctrine around the personality of the Emperor's grandson all illustrate the deep changes occurring within the Twelve Tribes as well as its impact on the larger international Rastafari movement. The return of the Twelve Tribes of Israel to Ethiopia demonstrates the capacity of the Rastafari to control the organizational means and resources required to reach their promised land. As discussed in this article, the social space of return provides a heretofore unexplored counterpoint to the common assumption that Rastafari repatriation has not been sufficiently significant to warrant discussion, or that it has been nonexistent. The case of 
the Twelve Tribes illustrates how a little-known but determined organization is intimately related to return to Ethiopia, bearing testimony to both a deeply imagined and profoundly real relationship between Africa and the Americas.

\section{References}

Barrett, Leonard E., 1997. The Rastafarians. Boston: Beacon Press.

Bedasse, Monique, 2010. Rasta Evolution: The Theology of the Twelve Tribes of Israel. Journal of Black Studies 40(5):960-73.

Bedasse, Monique, 2013. “To Set-Up Jah Kingdom”: Joshua Mkhululi, Rastafarian Repatriation, and the Black Radical Network in Tanzania. Journal of Africana Religions 1(3):293-323.

Bonacci, Giulia, 2013a. La fabrique du retour en Afrique: Politiques et pratiques de l'appartenance en Jamaïque (1920-1968). Revue Européenne des Migrations Internationales 29(3):33-54.

Bonacci, Giulia, 2013b. The Ethiopian World Federation: A Pan-African Organisation among the Rastafari in Jamaica. Caribbean Quarterly 59(2):73-95.

Bonacci, Giulia, 2014. Le retour en Éthiopie des Douze Tribus d'Israël. In Philippe Chanson, Yvan Dros, Yonathan N. Gez \& Edio Soares (eds.), Mobilité religieuse: Retours croisés des Afriques aux Amériques. Paris: Karthala, pp. 149-72.

Bonacci, Giulia, 2015. Exodus! Heirs and Pioneers, Rastafari Return to Ethiopia. Trans. Antoinette Tidjani Alou. Kingston: University of the West Indies Press.

Bracke, Sarah \& Stef Jansen, 1995. Dread in Babylon: An Explorative Field Study of the Twelve Tribes of Israel. In Robert Towler (ed.), New Religions and the New Europe. Aarhus: Aarhus University Press, pp. 211-23.

Campbell, Horace, 1994. Rasta and Resistance: From Marcus Garvey to Walter Rodney. Trenton NJ: Africa World Press.

Carrington, Vernon, 1997. Interview with Mrs. Andrea Williams. Running African, IRIE FM, July 13 .

Chevannes, Barry, 1998. New Approach to Rastafari. In Barry Chevannes (ed.), Rastafari and Other African-Caribbean Worldviews. The Hague: Institute of Social Studies, pp. 20-42.

Dijk, Frank Jan van, 1988. The Twelve Tribes of Israel: Rasta and the Middle Class. New West Indian Guide 62(1\&2):1-26.

Dijk, Frank Jan van, 1993. Jahmaica: Rastafari and Wider Society, 1930-199o. Utrecht: ISOR.

Dijk, Frank Jan van, 1995. Sociological Means: Colonial Reactions to the Radicalization of Rastafari in Jamaica, 1956-1959. New West Indian Guide 69(1\&2):67-101.

Dijk, Frank Jan van, 1998. Chanting Down Babylon Outernational: The Rise of Rasta- 
fari in Europe, the Caribbean, and the Pacific. In Nathaniel S. Murrell, William D. Spencer \& Adrian A. McFarlane (eds.), Chanting Down Babylon: The Rastafari Reader. Kingston: Ian Randle Publishers, pp. 178-98.

Fillmore, Charles, 1931. Metaphysical Bible Dictionary. Unity Village Mo: Unity School of Christianity.

Fillmore, Charles, 1995. The Twelve Powers of Man. Unity Village Mo: Unity Books.

Hepner, Randal, 1998a. Chanting Down Babylon in the Belly of the Beast: The Rastafarian Movement in the Metropolitan United States. In Nathaniel S. Murrell, William D. Spencer \& Adrian A. McFarlane (eds.), Chanting Down Babylon: The Rastafari Reader. Kingston: Ian Randle Publishers, 199-216.

Hepner, Randal, 1998b. "Movement of Jah People": Race, Class and Religion among the Rastafari of Jamaica and New York City. Ph.D. Dissertation, New School for Social Research, New York.

Homiak, John, 2013. When Goldilocks Met the Dreadlocks: Reflections on the Contributions of Carole D. Yawney to Rastafari Studies. In Jahlani Niaah and Erin MacLeod (eds.), Let Us Start with Africa: Foundations of Rastafari Scholarship. Kingston: University of the West Indies Press, pp. 56-116.

Murrell, Nathaniel S., William D. Spencer \& Adrian A. McFarlane (eds.), 1998. Chanting Down Babylon: The Rastafari Reader. Kingston: Ian Randle Publishers.

Owens, Joseph, 1995. Dread: The Rastafarians of Jamaica. Kingston: Sangster's Book Stores. [Orig. 1976.]

Price, Charles, 2009. Becoming Rasta: Origins of Rastafari Identity in Jamaica. New York: New York University Press. 